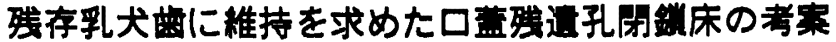

\author{
舘村卓・和田健・松槅和江・福田登弮子
}

\section{A new type of obturator with a supporting system on the remaining deciduous canine}

\author{
Takashi Tachimura - Takeshi WadA - Kazue MatuhashI \\ Tomiko FuxudA
}

\begin{abstract}
In order to obtain an effective closure of the anterior residual fistula following cleft palate surgery in case undergoing orthodontic treatment with brackets and arch wire, a new type of obturator seeking for its maintenance support to the remaining deciduous canine was invented. Its supporting system is constructed of a full cast metal crown for the palatally displaced deciduous canine as an abutment and the special clasp generating retaining force in cooperation with the metal crown. A case presented in this article showed an effective obturation and marked improvement in voice quality with this system.

The high points of the system are summarized as follows;

1) the remaining deciduous canine as an abutment for the obturator is available.

2) the system does not interfere with simultaneous orthodontic therapeutic procedures.

3) the patient can obtain a smooth and comfort environment for speech, since the supporting system between the abutment canine and the obturator can be designed to be small enough.
\end{abstract}

Key words: obturator 'orthodontic treatment' anterior oronasal fistula

\section{腥}

口蓋形成術術後に生じる牫遗孔は，頉度の高い口盖形 成術の合併庭であり，口蓋前方部から歯棤裂隌部にかけ

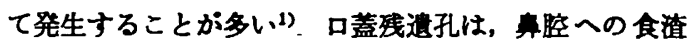
の流出のみならず, その位膡, 大きさ,ならびに形状によ って, 発音時には種々の異常構音の原因となることも指 摘されている2).この口蓋残遺孔の処居としては，外科 的手法あるいは閉鎖床などの非罯血的処直のいずれかが 選択されるが，外科的処置は，顥発育の旺盛な時期にお いては，その手術侵警による䫑発育を抑制する可能性が あるため，可及的に避けられることが望ましく，非㽙血 的手法の 1 つとしての閉鎖床が選択されることが多い. しかしながら，口蓋形成術術後においては，上歯列弓の

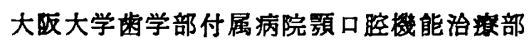

（主任：和田 健教授）

Division of Oral-Facial Disorders, Osaka University

Faculty of Dentistry (Chief: Prof. Takeshi Wada)

受付日：昭和63年 7 月 4 日

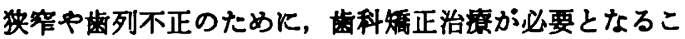
とが多く，矯正治㞠期间中の，閉鎖床の䊒持安定に関し ては，解決すべき問題を残している.

今回われわれは, 固定式矯正装置が装着された患者に

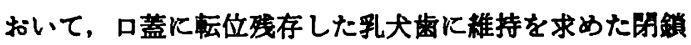
床を考案し，良好な維持安定をはかることができた症例 を経跧したので報告する。

症例

患 者: 12歳, 女性, 片側性唇額口蓋裂。

主 䂨: 番孔よりの食物の流出, 会話時の不明瞭な音 声.

既往歴・家族歴：ともに特記事項なし.

現病歴：1歳 7 か月時に口蓋形成術を受けた. 以後, 言語治療を受けていたが，家庭の事情により中断した. 6 歳時より，歯科稪正治療が開始され，治療の進行に伴 って食渣の县腔への漏出が著明となったが，上額齿列払 大治療中であるとのことで外科的残遗孔閉鎖術や閉鎖床 装置による処置す行われずに経過した. 


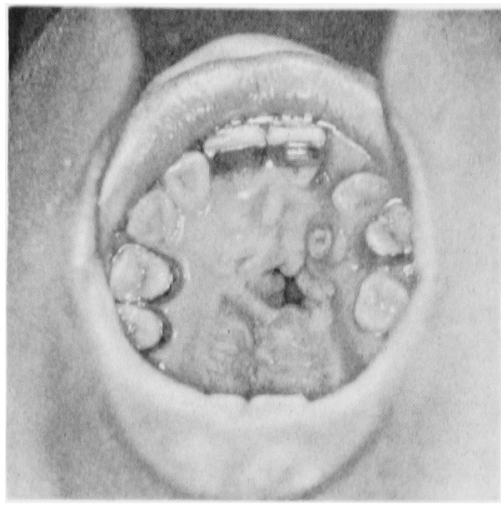

写直 1 口腔内军

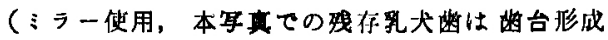
が䅂了している)
口腔内所胃：641!123456に修列の侧方抬大を目的と

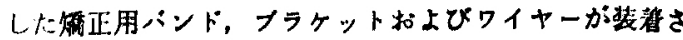

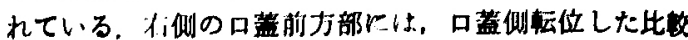

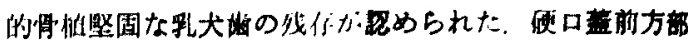

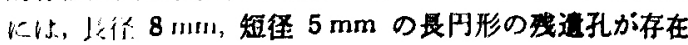

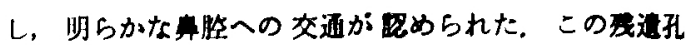

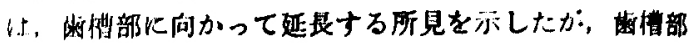

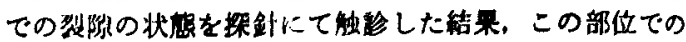
舞临侧への交通は跑められなかった（写西1）。

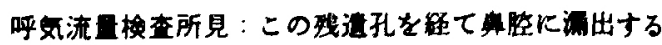

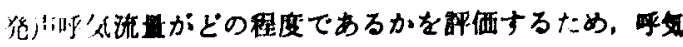

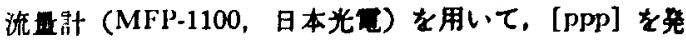

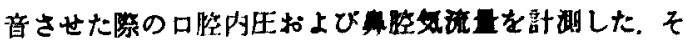

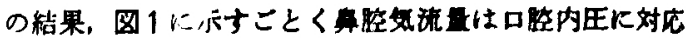
して增加するのが银められた。

咽腔内視鉷所見：主柝としての不明睡な音声が，唯

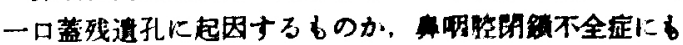

音声

口腔内压

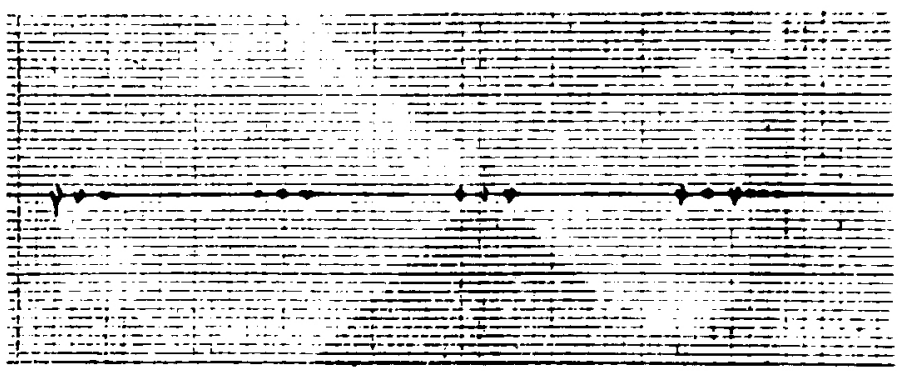

$\because$
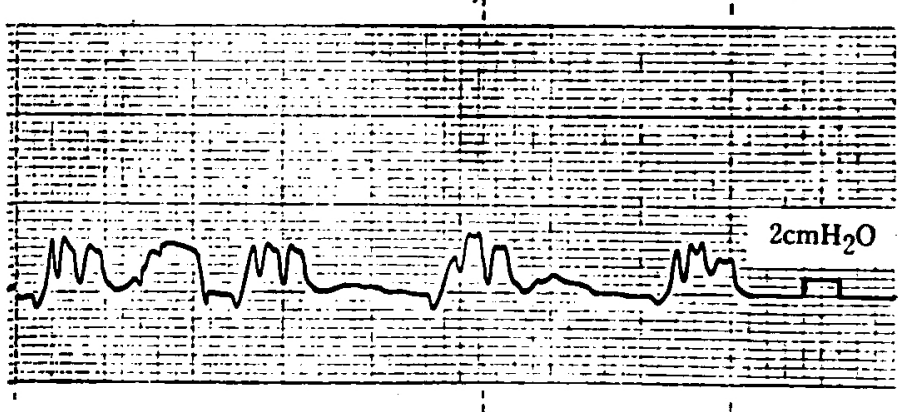

腔気流是

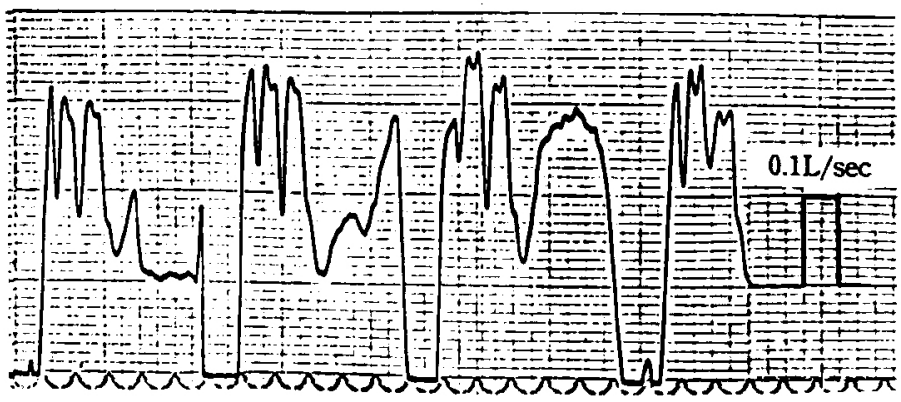

图 1 末装着時の呼気流量检査結果 


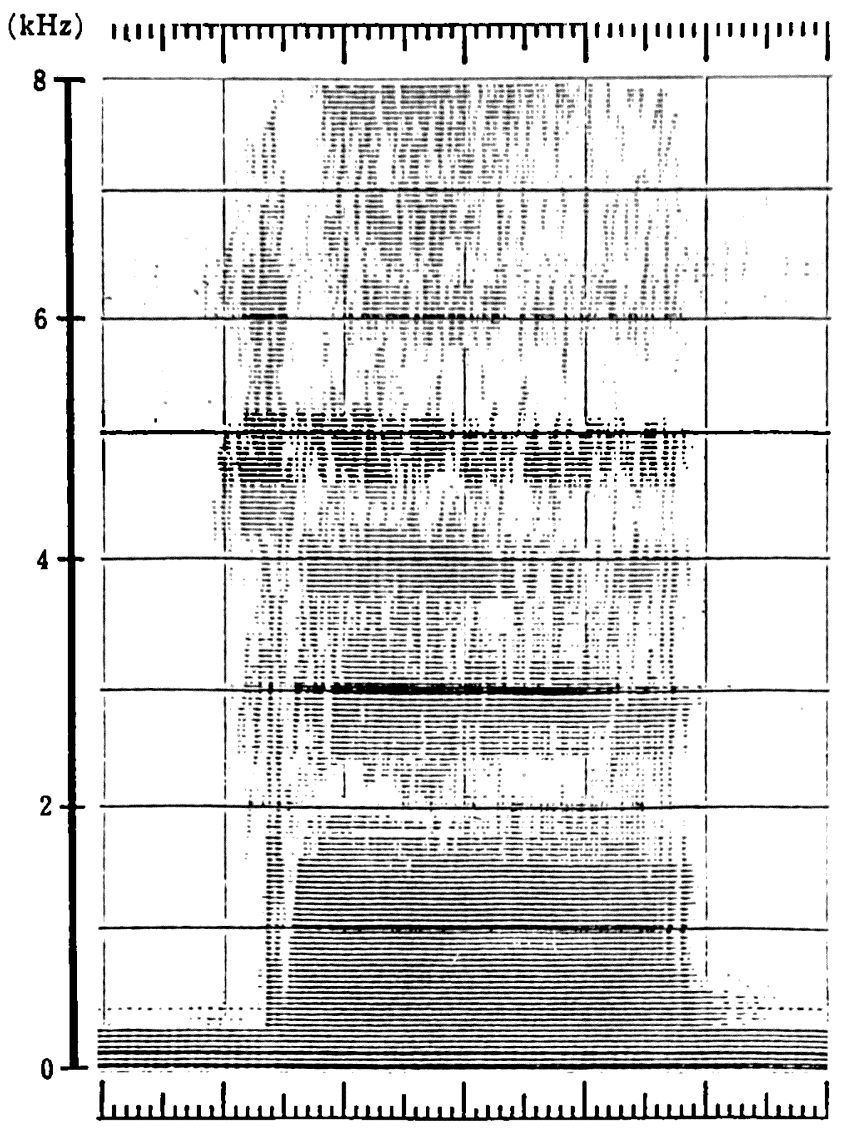

图 2 末装着時の [p] の soundspectrogram

（表出時間の長い摩掏子音様の fill が認められる）

基つくすのであるかを，検討するために，日本語子音 （破裂音，摩擦音，破擦音，弾音）ならびに母音につい、 て，単音および連続音発音時における年咽腔閉鎖状態を 臭咽腔内視鏡 (NPF，オリンパス) を用いて観察した。 その結果, おのおのの単音において算咽腔の完全閉鎖, また連続音の語音間においても，臭咽腔の完全閉鎖が達 成されている所見が得られた。

昌声所見：日本語単音節 (109 音節) の音読ならびに 会話を録音テープに録音し, 聴覚印象および soundspectrogram に基づいて判定した。聴覚印象の結果，歯荎お よび口唇破裂音の子音部に㧍ける破裂性が減弱し，摩擦 成分が混入している音として聴取され，また無声破挜音 が軟口蓋音に圈換していた. soundspectrograph (Digital Sona-Graph 7800，KAY) を用いて 作製した破裂音の soundspectrogram の内, [p] についての結果を図 2 K 示す. 通常, 正常音声の破裂音の soundspectrogram 上 において認められる spike fill に相当する部分の表出時 間が長く，摩摖子音に恐められるような fill を示してい
た.

以上の検査結果から，本症例における息咽腔閉鎖妓能 は良好であり，主訴における各障害は，口蓋残䢖孔から の呼気および食渣の鼻腔への漏出が原因であることが判 明した。

\section{作}

本症例では，現在払大矯正治療中であることから，锶 血的処置では術後に再発する可能性があると判断し，非 観血的処着としての閉鎖床を装着することにした。しか しながら，従来用いられてきた歯槽上雪牙に椎持を求め る閉鎖床では，拡大知正治療を阻害せずに㗨密な閉鎖を 行うことがでさない，本症例では，残遺孔辺緑に口蓋側 転位した 比較的骨植堅固な $\mathrm{C} \mid$ が残存しているのが認め られたため，通常，要拔去歯牙とされる $\mathrm{C}$ に稚持を求 める方法を検討した，作製に踏しては，閉鎖休装着によ る逜物感を可及的に低減し，新たに異常構音を惹起しな 


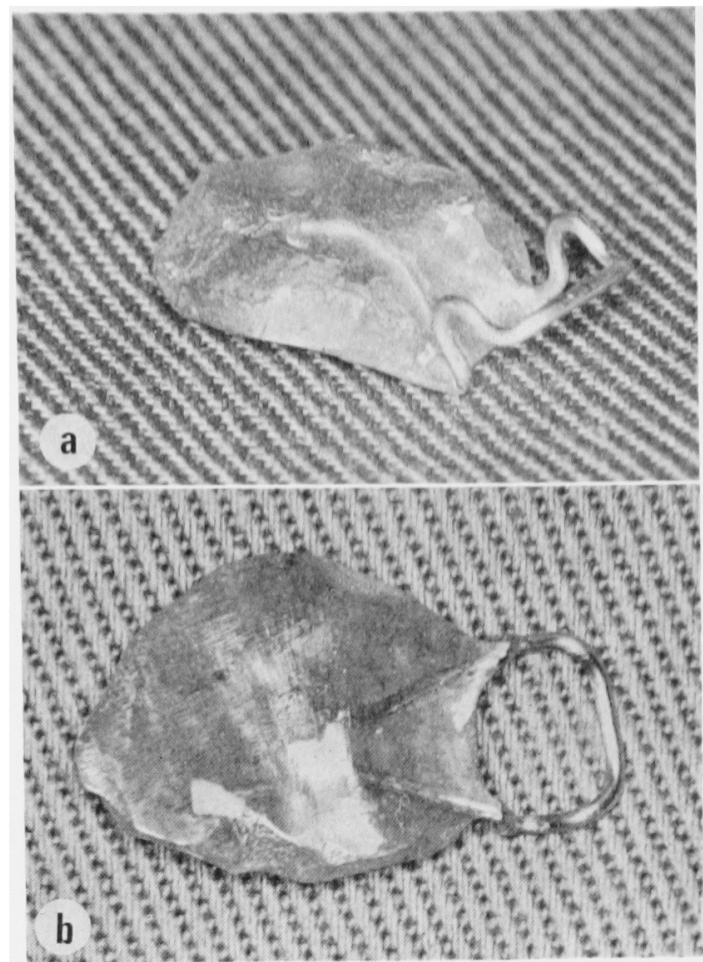

写素 2 成鎖床外钼
a) 鼻腔側面
b）口腔側面

いこと、ブラケット，ワイヤーなとの知正畒の装着和 よび治療効果を阻害しないことを主眼とした。

閉鎖床の維持を 形態が円錐状であることから，フンダーカットに鈎端が 入り込むことによって維持を図る鈎は適用できない，そ こて，拔咀処直，支台筑造および支台形成を行い，閉鎖 床の稚持装膡に歯冠形態が適合し得るように全部鋳造冠 を作製し，この全部鋳造冠に応じた钧を考案し閉鎖床に 装着した。

作製した閉鎖床の外観を写开 2 K，また写甹了に装着 時の口腔内钼を示す，閉鎖床の維持力は，图了に示すよ 5な全部筹造冠（以後，牫遗孔に面する壁面を孔側面， 残遣孔から見て遠心側面を頓側面，孔側面頓側面に直交 する壁面を隣接面，および上面を咬合面と呼称する）の 両隣接面と鈎の $\mathrm{arm}$ および孔側面と対応する閉鎖床粘 膜面との間の接触抵抗によって発生する. 全部鋳造冠の 形態は，孔側面および両隣接面を床の着脱方向に奶して 平行に，また両隣接面は相互に平行になり，なおかつ孔 側面に対しては直交する平面とした．熲側面には，釣の 煩側部が入り込む sholder を設けることによって，休の 過剩な沈下を防止した。 孔側面は，着脱方向に平行な平 面で仕上け゚，㦿との間の接触抵抗を高め，また装着時の 誘導面となるよらにした。

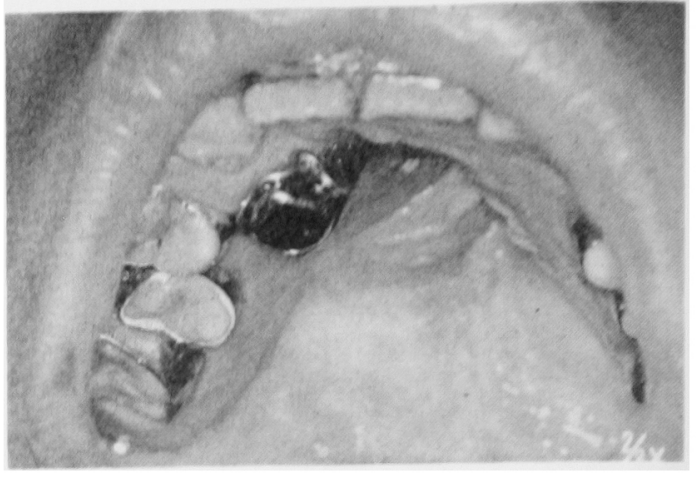

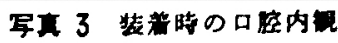

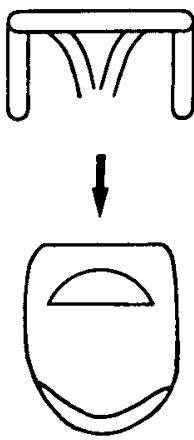

頼側面観

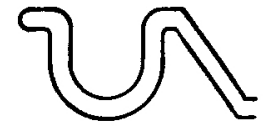

1

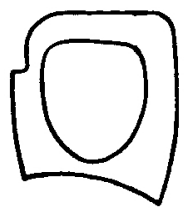

接接面锶

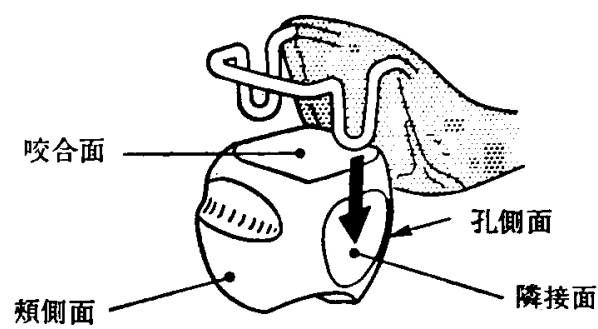

因 3 作繁した全部壎造冠と物

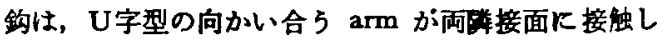
て維持力を発生し，䊒持力の調培は arm の内㑡への㑯 斜角度を变化させることにより行えるようにした，床の

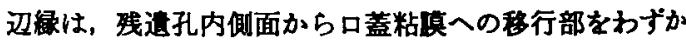
に超え，连物感の低娍を図るために口蓋粘膜面と連舶的 に移行するよ5に設定した。閉鎖休基腔側面の高さは, 租腔粘膜に対しては障害を与えず，なおかつ呼気や食盗 の流れに対しては高い抵抗を示すよらに，牫遗孔内面の 最大突出部に設定した。 また，全部鋳造冠孔側面に接触 する閉鎖床粘獏面は，鈎の煩側部を中心とする回転運動 による床の脱落を防止し，なおかつ接触抵抗を高めるた 

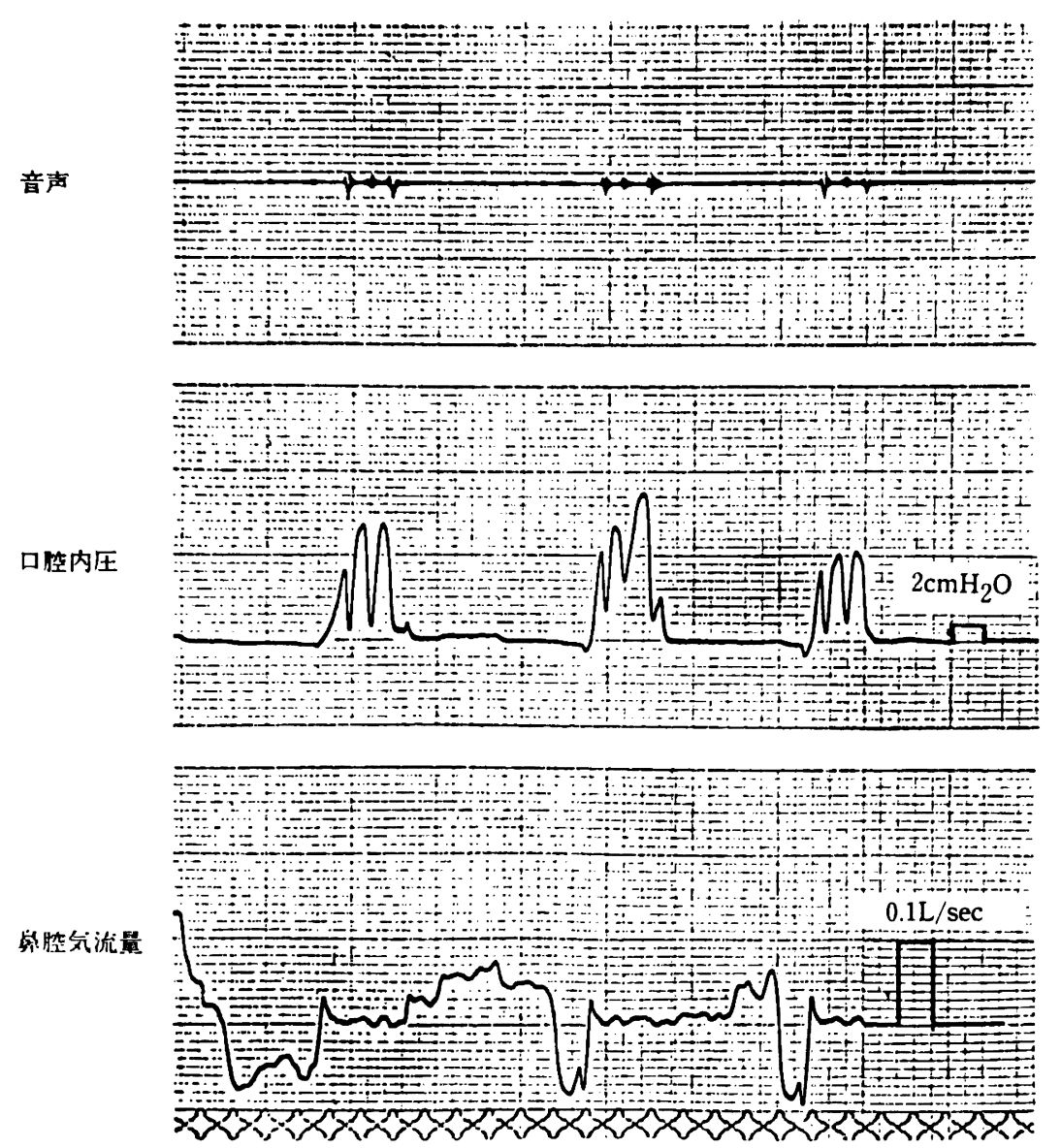

图 4 装着時の呼気流量检查枯果

めに全部鋳造冠の 孔側咬合辺緑隅角まで覆らようにし た.

結果

\section{呼気流量検查結果}

閉鎖床が未装着の際は, 破裂音発音時に口腔内王の上 䄯に対応して其腔通気量が增加していた（図1）が，装 着後は図 4 に示すよ5に，口腔内圧が破裂音発音に必要 とされるる3 $2.2 \mathrm{cmH}_{2} \mathrm{O}$ 以上を示しても, 呼気の番腔漏 出を示す其腔気流は検出されず, 閉鎖床が有効であるこ とが示された。

\section{音声所見}

图 5 K，閉鎖床装着下での [p] 発音時の soundspectrogram を示す，末装着での soundspectrogram（図2） では㮮擦音様の表出時間の長い, fill を示していたが，装 着下では, 正常破裂音の spike fill に近似した fill にな っており，閉鎖床によって発音時の口腔内王が上昇し破
裂性が生じていることが示され，音掣学的にす改善が認 められた。

\section{考寞}

口蓋形成術，とくに粘膜骨膜弁後方移動術術後におい、 ては，前方および側方への䫁発育が抑制される結果，上

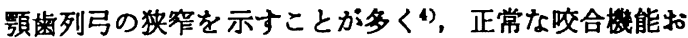
よび発音機能の付与には雪科稫正的に上額崡列弓の払大 治療が必要である.しかしながら，上顥雪列弓の払大治 療を開始することによって，口居形成術術後には molding effectsによって物理的に閉じられ，表出音声の音 質に影警を及ほささない程度の大きさであった裂隙や歯槽 口蓋部に存在する残遗孔が影性化することがある.この ような残遺孔によって生じる音声上の歪みとして，母音 では其音化すること, 破裂性子音や摩撩性子音では子音 成分が欠落することや，それらの子音を表出する侮に必 要な口腔内圧を得るために舌をるって残遺孔を塞ぐこと 


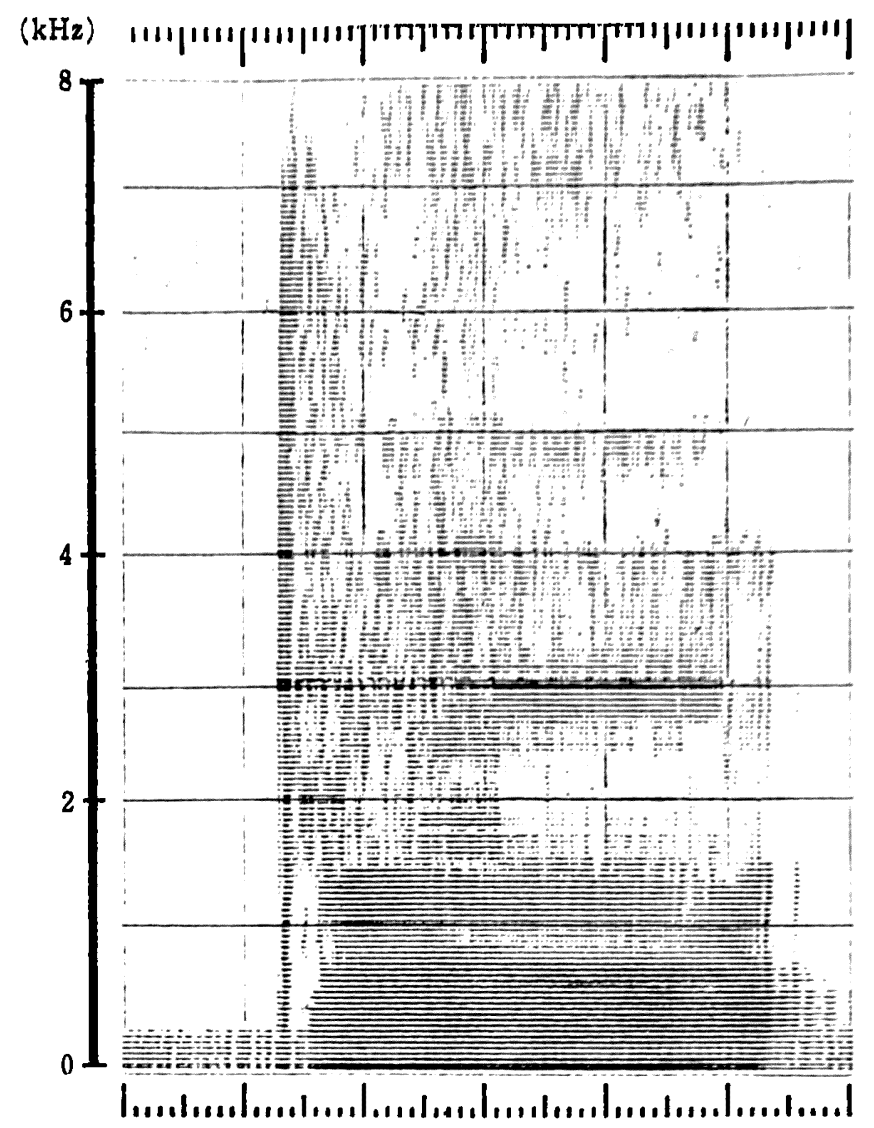

图 5 装盖時の [p] の soundspectrogram

（子音部は，破裂音漛の spike fill 飞变化している）

とよって生じる異常構音方法，また残息孔を呼気が通過 すること火よって生じる雅音が混入することなどがあげ られる. この牫造孔対する処置として，口腔外科的な 閉鎖手術や閉鎖床の装着が一般的に講しられているが，

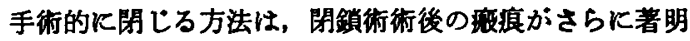
となること火よって, 㑡方払大治瘿を阻害する可能性か ある"，他方，閉鎖床を用いる方法は，稚持を左右雪列 弓に求めた場合, 払大治察の奻果を減弱することや，閉 鎖床が扗大床を兼ねている场合，埋没した screw の部 分より呼気が漏出することによって，残遗孔の閉鎖機能

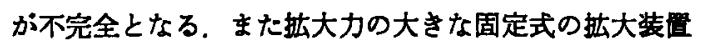
が装着されている場合には，閉鎖床の維持が困難であ る. 固定式の払大装置が装着されている症例に対して, 㜞性レシンの弾性を利用して残遗孔自体火維持を求める 様式の床装置( が用いられる場合すあるが，樹脂の特性 として経時的便化収縮することや樹脂に付着した食渣 中 candida Kよる denture plaque によって発話時の 呼気化異臭が認められること，番腔㑡維持部の大きさや

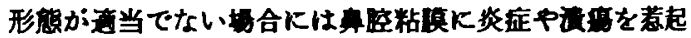
することなどにより，装着後る堆持や管理のために願回 の受診調塣を要する. そのため，学盍期の患者に奶して

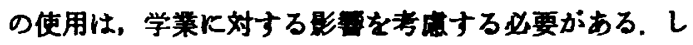

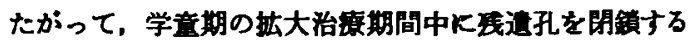
手段としては，口腔外科的な手法や拆大治度を行ってい る齿牙や残造孔そのるのに赫持を求めた床装置ではな く，他の固定源に 蓷持を求めた閉鋇床による必要があ る.

稪正治痕においては，永久齿列弓における正常咬合の 付与を最釉的な治窥の目的としているため，永久齿列弓

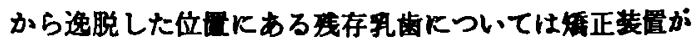
装着されることなく放居されることが多い，加えて，そ のような残存乳齿はフンダーカットが小さく钲視できる 程度の小窝裂溝しかるたない釈前齿であることが多いた め，5蝕に䍜患していてる基度であり，また永久齿列弓 より逸脱しているため後続永久崡による雪根吸収る生し ておらず，堅固な骨植状態であることが多い．したがっ 
て，閉銷床の固定源として選択し得る齿牙であると孝え られる. しかしなからら，乳前齿や乳犬齿本来の歯冠形想 のままでは，鈎の形態や維持のためのフンダーカットの 位置や旦が規制されるため，閉銷床を維持するために必 要十分な維持力を鈎に付与できない，そこで，本症例て は床脱落に抗するに十分な維持力を発生し、なおかつ鈎 歯を移動挺出させない釣を設計するために，齿冠形惩を 自由に変え得る全部錛造冠を装着した。

以上の方法によって，流動食椬の宜孔よりの流出は認 められなくなり，非鼻音性子音発音時においてす著明で あった算乘音が消失し，正常子音に近い聴觉印象が得ら

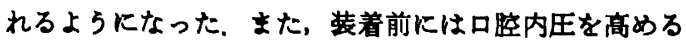

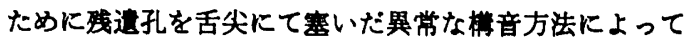
発音していたが，閉鎖床装着と粠音治潦によってその異 常粹音も消失する傾向にある。

\section{結語}

歯列拡大治償中であることから，処直されずに放置さ れていた口蓋残遗孔のために，食渣の宜孔よりの流出， 表出語音の不明瞭性を主訴とする症例に対して，残遗孔

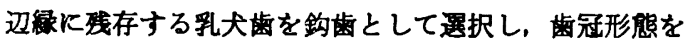
調整した全部鋳造冠を装着し，鋳造冠の崡冠形態に呼応 して維持力を発揮するよ5作製した鈎をるつ閉鎖床を装 着することによって以下に示す良好な結果を得た。

1. 歯列稪正治㞠の対象からはずれた残存乳大雪を鈎 每としたため，稪正治㞠を阻害せずに良好な閉鎖床の維 持が得られた。

2. 鈎歯となる残存乳犬柴が残遗孔辺緑に 存在してい たため, 左右齿列弓に維持を求める閉鎖床と比較して小 さな床面積となった，そのため，異物感が軽減され，ま た新たな異常構音を䓯起することなく閉鎖機能を付与で
きた。

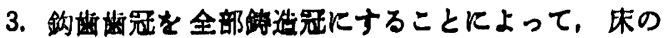

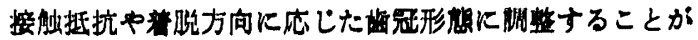

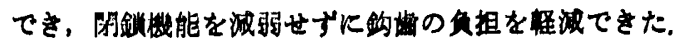

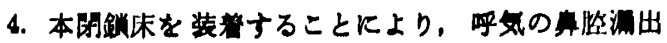
を瞣めることなく破裂音発音に必要な $2.2 \mathrm{cmH}_{2} \mathrm{O}$ 以上 の口腔内王が得られた。

5. soundspectrogram 分析の結果，装曾部の破列音発

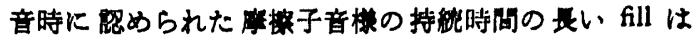

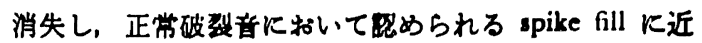
似していた。

本研究の一部は，昭和62年度文部少科学研究费䊇助会 （総合研究 A：踝睤番号 62304050）によった。

\section{引用 文 献}

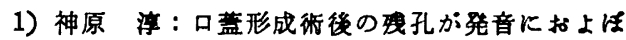
す影签に闺与万研究，九州会誌 28：688-710 1975.

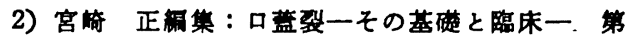
1 版, 医曾蔊出版，東京，1983，432-435頁.

3）松矢第三：口蓝裂患者の異常音声の発声楮序

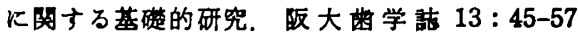
1968.

4) Pruzansky, S.: Factors determining arch form in clefts of the lip and palate. Amer. J. Orthodont. 41: 827-851 1955.

5）宮崎正編集：口蓝裂一その基硞と臨床一，第 1 版, 医药出版, 東京, 1983，443頁.

6）福田登美子，西村敏治，他：口蓝裂犹後戏遣孔 に対する閉鎖床の一試案. 日口外誌 25：2032091979. 